ARTICLE

DOI: $10.1038 / s 41467-018-06708-x$

\title{
Raising the redox potential in carboxyphenolate- based positive organic materials via cation substitution
}

\author{
Alia Jouhara', Nicolas Dupré ${ }^{1}$, Anne-Claire Gaillot ${ }^{1}$, Dominique Guyomard', Franck Dolhem ${ }^{2,3}$ \& \\ Philippe Poizot $\mathbb{1}^{1,4}$
}

Meeting the ever-growing demand for electrical storage devices requires both superior and "greener" battery technologies. Nearly 40 years after the discovery of conductive polymers, long cycling stability in lithium organic batteries has now been achieved. However, the synthesis of high-voltage lithiated organic cathode materials is rather challenging, so very few examples of all-organic lithium-ion cells currently exist. Herein, we present an inventive chemical approach leading to a significant increase of the redox potential of lithiated organic electrode materials. This is achieved by tuning the electronic effects in the redox-active organic skeleton thanks to the permanent presence of a spectator cation in the host structure exhibiting a high ionic potential (or electronegativity). Thus, substituting magnesium (2,5dilithium-oxy)-terephthalate for lithium (2,5-dilithium-oxy)-terephthalate enables a voltage gain of nearly $+800 \mathrm{mV}$. This compound being also able to act as negative electrode via the carboxylate functional groups, an all-organic symmetric lithium-ion cell exhibiting an output voltage of $2.5 \mathrm{~V}$ is demonstrated.

\footnotetext{
${ }^{1}$ Institut des Matériaux Jean Rouxel (IMN), UMR CNRS 6502, Université de Nantes, 2 rue de la Houssinière, B.P. 32229,44322 Nantes Cedex 3, France. ${ }^{2}$ Laboratoire de Glycochimie, des Antimicrobiens et des Agroressources (LG2A), UMR CNRS 7378, Université de Picardie Jules Verne, 33 rue Saint-Leu 80039 Amiens Cedex, France. ${ }^{3}$ Réseau sur le Stockage Électrochimique de l'Énergie (RS2E), FR CNRS 3459, France. ${ }^{4}$ Institut Universitaire de France (IUF), 1 rue Descartes, 75231 Paris Cedex 05, France. Correspondence and requests for materials should be addressed to P.P. (email: philippe.poizot@cnrs-imn.fr)
} 
R echargeable lithium-ion batteries (LIBs) used in portable electronic devices now number well over a billion units per year, and mid-term growth is expected. The pressure on the LIB market is further accentuated by the widespread global development of electric mobility which is naturally aligned with the emerging socio-technical transition. Being faced with such a high worldwide battery demand raises issues concerning resource availability and recyclability, which are further compounded by the challenges of providing the necessary technical requirements in terms of capacity, energy density, cyclability, safety and cost. This statement having naturally been anticipated ${ }^{1}$, numerous research efforts have been pursued in the quest for alternative chemistries. Among these, Li-S, Na-ion and metal-air systems have emerged as promising post Li-ion technologies ${ }^{2-9}$. After years of relative silence, the possibilities offered by organic electrode materials have also re-emerged in the energy storage community ${ }^{10}$ - particularly following the development of the socalled organic radical batteries pioneered by the Nippon Electric Company (NEC) and Nishide and colleagues ${ }^{11-15}$-opening up many interesting opportunities such as design flexibility, lighter weight, lower cost and/or a tempered environmental burden ${ }^{2,10}$. Moreover, these materials offer the possibility of extending the conventional reversible cation uptake/release electrochemical mechanism (with n-type organic redox center) to include an anion-inserting process (with p-type organic redox center) ${ }^{16-18}$. They also unveil a whole new arena by making way for the design of organic electrochemical storage systems, including the development, in theory, of metal-free (molecular) ion batteries ${ }^{16,19-23}$. To date, a myriad of promising electroactive organic materials for application in non-aqueous (metallic) Li- or Na-based batteries have been investigated, leading to the publication of several reviews on the topic ${ }^{9,15,24-29}$. More recently, K-, Mg- and Alinserting organic electrodes have also been investigated ${ }^{30-34}$. It should be mentioned that water-based electrolytes are also being considered with respect to promoting low-cost organic batteries $^{35-37}$ due to their continued promising performance in redox flow technology, achieved by combining natural quinones and aqueous electrolyte media, notably thanks to the works of Aziz and authors ${ }^{38-43}$.

However, as recently underlined ${ }^{23}$, very few examples of allorganic Li-ion cells have been reported in the literature because of the inherent difficulty in designing efficient lithiated organic cathode materials, as opposed to their inorganic counterparts (e.g., $\mathrm{LiCoO}_{2}, \mathrm{LiNi}_{1 / 3} \mathrm{Mn}_{1 / 3} \mathrm{Co}_{1 / 3} \mathrm{O}_{2}$ or $\mathrm{LiFePO}_{4}$ ). Our group was the first to report an all-organic Li-ion cell based on renewable raw materials, by virtue of the amphoteric redox property of $\mathrm{Li}_{4} \mathrm{C}_{6} \mathrm{O}_{6}$ (Supplementary Fig. 1a) which led to the design of a cell exhibiting an $\sim 1 \mathrm{~V}$ output voltage ${ }^{44,45}$. This redox effectiveness of conjugated Li-enolate moieties $(=\mathrm{C}(\mathrm{OLi})-)$, as well as the synchronous discovery of the reversible reduction process associated with the carboxylate functional groups in terephthalate at very low potential $\left(\sim 0.8 \mathrm{~V} \mathrm{vs.} \mathrm{Li}^{+} / \mathrm{Li}\right)^{46}$, prompted us to investigate the electrochemical behavior of dilithium (2,5-dilithium-oxy)-terephthalate (denoted $\mathrm{Li}_{4}-p$-DHT) ${ }^{47}$ as a promising dual-function electrode for a second generation of all-organic Li-ion cells, also entirely derived from renewable resources (Supplementary Fig. 1b). To date, Chen and colleagues ${ }^{48}$ has reported the best performance with this material, on condition that it is prepared in the form of nanosheets in order to reach its full theoretical capacity. As a result of the two-electron reactions formally occurring between $\mathrm{Li}_{2}-p$-DHT/Li 4 - $p$-DHT at $\sim 2.6 \mathrm{~V}$ on the positive electrode side and $\mathrm{Li}_{4}-p-\mathrm{DHT} / \mathrm{Li}_{6}-p-\mathrm{DHT}$ at $\sim 0.8 \mathrm{~V}$ on the negative electrode side, respectively, this all-organic Li-ion cell exhibits an average operating voltage of $1.8 \mathrm{~V}$ and an energy

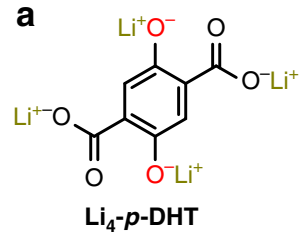

b

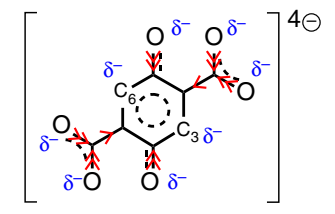

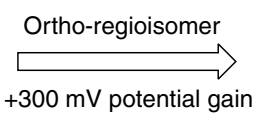

+300 mV potential gain

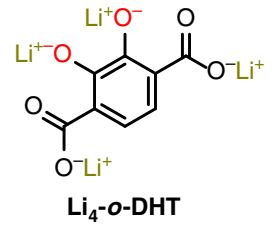

C

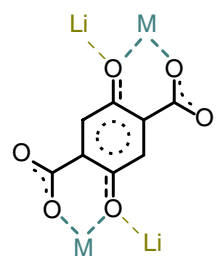

Fig. 1 Electronic effects and potential tuning. a Formal potential increase when switching from para- to ortho-regioisomer in $\mathrm{Li}_{4} \mathrm{DHT}^{51}$. b Limiting structure (hybrid) of the tetranionic $p$-DHT ligand together with partial charges (in blue). The red arrows conventionally indicate the donor inductive effect $(+\mathrm{I})$ related to both phenolate and carboxylate substituent groups. c Illustration of the chelating bonding mode between the tetranionic ligand and countercations based on crystallographic data reported for MOFs containing $p$-DHT as polytopic linker (i.e., $\mathrm{Li}^{+}$and a spectator cation $\mathrm{M}^{n+}$ ); the nature of $\mathrm{M}-\mathrm{O}$ bonds can affect the electronic distribution along the aromatic system

density of about $130 \mathrm{Wh} \mathrm{kg}^{-1}$ together with a long cycling life (1000 cycles) when supported on graphene ${ }^{49}$. This fascinating organic skeleton urged us to further investigate the possibilities offered by its molecular engineering, especially with respect to increasing the formal redox potential of the Li-diphenolate ring. An obvious and attractive aspect of its organic chemistry is the multiplicity of possible chemical combinations at the molecular level giving rise to an incomparable tool for tuning several properties. This notably includes the redox potential, especially in conjugated systems when playing with both inductive and mesomeric effects ${ }^{50-52}$. Having decided to explore this avenue first, (i.e. focusing on the tuning of the organic part), the simplest strategy was to take advantage of the well-known phenomenon in molecular electrochemistry ${ }^{50}$ whereby a positive potential shift occurs when switching from the para- to the ortho-position in the quinone/hydroquinone moiety (Fig. 1a). After having made the appropriate adjustments to our initial synthesis approach, formerly developed for $\mathrm{Li}_{4}-p$-DHT, we succeeded in preparing the ortho-regioisomer, namely dilithium (2,3-dilithium-oxy)-terephthalate $\left(\mathrm{Li}_{4}-o-\mathrm{DHT}\right)^{51}$, and demonstrated an interesting voltage gain of $+300 \mathrm{mV}$ compared to $\mathrm{Li}_{4}-p$-DHT in the solid state, although this gain was not high enough to compete with $\mathrm{LiFePO}_{4}$, a common inorganic insertion electrode material used in commercial LIBs.

In the interest of surpassing this, we herein specifically report on the synthesis and electrochemical performance of magnesium (2,5-dilithium-oxy)-terephthalate (denoted $\mathrm{Mg}\left(\mathrm{Li}_{2}\right)$ - $p$-DHT) as a very promising lithiated positive material able to cycle at near 3.4 $\mathrm{V}$ vs. $\mathrm{Li}^{+} / \mathrm{Li}$ thanks to the presence of a magnesium cation in its chemical structure; a spectator ion exhibiting a high ionic potential value. Data on $M_{2 / n}^{n+}\left(\mathrm{Li}_{2}\right)$-p-DHT counterparts with $\mathrm{M}^{n}$ $+=\mathrm{Li}^{+}, \mathrm{Ca}^{2+}$ and $\mathrm{Ba}^{2+}$ are also provided to better understand the effect of the substitution chemistry on the redox properties of the Li-diphenolate ring in the tetranionic $p$-DHT ligand. As previously observed with the two regioisomers of $\mathrm{Li}_{4} \mathrm{DHT}^{47,51}$, we demonstrate that the reversible capacity is still limited to half of the theoretical value in our experimental conditions probably due 
to the high stability of the electrogenerated radical anion in the solid state. Last but not the least, in $\mathrm{Mg}\left(\mathrm{Li}_{2}\right)$-p-DHT, being also reversibly electroactive in reduction through its carboxylate functional groups, the assembly of an all-organic symmetric Liion cell is shown exhibiting $2.5 \mathrm{~V}$ as output voltage.

\section{Results}

The concept. Inspired by the works of Lewandowski et al. ${ }^{53}$ pointing out the correlation between the perturbation of the electronic system of aromatic ligands (including 2-hydroxybenzoate, a parent structure of our ligand) and the position of the countercation in the periodic table, in this communication we demonstrate an equally intriguing approach for increasing the formal potential of redox-active conjugated Li-diphenolate ring in the $p$-DHT system by modifying the chemical nature of the spectator cation which formally compensates for the negatively charged carboxylate substituent groups. To better grasp this keen chemical stratagem based on the tuning of the p-electron density distribution in the aromatic skeleton, it is worth going over the electronic effects occurring in our tetranionic ligand. Figure $1 \mathrm{~b}$ shows its limiting structure (hybrid) together with the inductive donor effect $(+\mathrm{I})$ of both $-\mathrm{O}^{-}$and $-\mathrm{COO}^{-}$substituent groups. In short, one notes that the $\mathrm{C}(3)$ and $\mathrm{C}(6)$ carbon atoms (formally involved in the conjugated Li-diphenolate ring) display a higher electron density through mesomeric effects, while the four electron-donating substituent groups enrich the ring thereby making the diphenolate ring more reducing, which explains the resulting relatively low formal potential observed with $\mathrm{Li}_{4}-p$-DHT $\left(\sim 2.6 \mathrm{~V}\right.$ vs. $\left.\mathrm{Li}^{+} / \mathrm{Li}\right)$. However, the presence of $-\mathrm{COO}^{-}$groups remains essential in order to ensure a very low solubility of the organic material in the carbonate-based liquid electrolyte $9,15,47,51,54-57$. Figure $1 \mathrm{c}$ illustrates the chelating bonding mode between the organic tetraanion and the countercations (while maintaining $\mathrm{Li}^{+}$on the phenolates), based on crystallographic data reported for metal organic frameworks (MOFs) using $p$-DHT as polytopic linker ${ }^{58,59}$. The nature and position of the metal has an influence on the $\mathrm{M}-\mathrm{O}$ bonds, and this effect is transferred to the $\mathrm{C}-\mathrm{O}$ bonds causing changes in the electronic distribution in the ligand. The stabilization (or destabilization) of the aromatic system thus depends on the choice of spectator cation $\mathrm{M}^{n+}$ and its relative ionic potential (or its electronegativity $)^{53}$. Therefore, cations exhibiting a low ionic potential value should destabilize the distribution of p-electron density because they make weak bonds with oxygen atoms. Among the cations studied by Lewandowski et al. ${ }^{53}$ that stabilize the distribution of p-electron density (and that should increase the formal redox potential), magnesium was specifically selected for its abundance, low cost and low atomic weight. We also specifically decided to prepare the $\mathrm{Ba}\left(\mathrm{Li}_{2}\right)-p$-DHT counterpart for comparison purposes since $\mathrm{Ba}^{2+}$ is also an alkaline-earth metal like $\mathrm{Mg}^{2+}$ but its ionic potential value is interestingly quite close to that of the Li alkali (Supplementary Table 1). Finally, $\mathrm{Ca}\left(\mathrm{Li}_{2}\right)$ $p$-DHT was also integrated for making further comparisons.

Preparation and characterizations of $\mathbf{M g}\left(\mathbf{L i}_{2}\right)-p$-DHT. A green approach was used to synthesize the $\mathrm{Mg}\left(\mathrm{Li}_{2}\right)-p$-DHT. The first step consisted in neutralizing the two carboxylic functional groups of 2,5-dihydroxyterephthalic acid $\left(\mathrm{H}_{4}-p-\mathrm{DHT}\right)$ with a stoichiometric amount of magnesium hydroxide in water, under ambient atmosphere. Interestingly, after evaporation of the water under reduced pressure, this route promptly produced a batch of pure single crystals of $\mathrm{Mg}\left(\mathrm{H}_{2}\right)-p-\mathrm{DHT}\left(\mathrm{H}_{2} \mathrm{O}\right)_{5} \cdot \mathrm{H}_{2} \mathrm{O}$, as deduced by $\mathrm{X}$-ray diffraction (XRD). The corresponding structure comprises five water molecules coordinated to the $\mathrm{Mg}$ cation bonding the $p$-DHT units, with one additional water molecule located in the inter-sheet spaces (Supplementary Fig. 2 and Supplementary Table 2). An equivalent structure was recently published by Henkelis et al. ${ }^{60}$, although a distinctly different synthesis approach was used. The as-produced organic salt was also characterized by thermal analysis, Fourier-transform infrared spectroscopy (FTIR) measurement and liquid/solid nuclear magnetic resonance (NMR) spectroscopy (Supplementary Fig. 3). The second step concerned the neutralization of the two phenolic groups in the presence of two equivalents of lithium hydroxide in water, under inert atmosphere. The heterogeneous yellow medium was then dried under vacuum at room temperature until an orange residue was obtained. The resulting orange powder was first characterized by FTIR and then by ${ }^{1} \mathrm{H} /{ }^{13} \mathrm{C}$ liquid NMR spectroscopy (Supplementary Fig. 4), which led to the conclusion that a hydrated form was obtained. Figure $2 \mathrm{a}$ shows both the thermogravimetry (TG) and differential scanning calorimeter (DSC) curves, measured either under argon or air, together with the corresponding mass spectrometry data. Unambiguously, the first weight loss of $\sim 10.2 \%$ at $100{ }^{\circ} \mathrm{C}$, associated with an endothermic phenomenon, corresponds to the release of one water molecule (as detected by mass spectrometry (MS)) giving rise to the following chemical formula: $\mathrm{Mg}\left(\mathrm{Li}_{2}\right)-p-\mathrm{DHT} \cdot \mathrm{H}_{2} \mathrm{O}$. The second large weight loss, occurring at $350{ }^{\circ} \mathrm{C}$ (under air) or at $600{ }^{\circ} \mathrm{C}$ (under argon), involves an obvious thermal decomposition of the compound. Note that $\mathrm{Mg}\left(\mathrm{Li}_{2}\right)-p$-DHT exhibits a good thermal stability up to about $250^{\circ} \mathrm{C}$ in air, which is an important factor in the safety of rechargeable batteries. The analysis of $\mathrm{Mg}\left(\mathrm{Li}_{2}\right)-p$ $\mathrm{DHT} \cdot \mathrm{H}_{2} \mathrm{O}$ by temperature-resolved X-ray powder diffraction (TRXRPD) collected under $\mathrm{N}_{2}$ from room temperature up to 200 ${ }^{\circ} \mathrm{C}$ (Fig. 2b) revealed the occurrence of a phase transition process yielding the corresponding anhydrous phase as confirmed by FTIR measurement (Supplementary Fig. 4a).

After an isotherm step at $200^{\circ} \mathrm{C}$ for $16 \mathrm{~h}$, the sample (always inside the XRD high temperature chamber) was cooled down to $20^{\circ} \mathrm{C}$ and subsequently exposed to various gas flows $\left(\mathrm{N}_{2}\right.$, air, and finally pure $\mathrm{O}_{2}$ for $15 \mathrm{~h}$ each, Fig. $2 \mathrm{~b}$ ) in order to further study the chemical stability of the as-obtained anhydrous $\mathrm{Mg}\left(\mathrm{Li}_{2}\right)-p$-DHT phase. Interestingly, no changes were observed-contrary to those noted for two regioisomers of $\mathrm{Li}_{4} \mathrm{DHT}^{47,51}$ - thus indicating a good stability against $\mathrm{O}_{2}$ oxidation, and thereby supporting our strategy of replacing $\mathrm{Li}^{+}$with $\mathrm{Mg}^{2+}$ in order to mitigate the donor inductive effects in the ring. The anhydrous $\operatorname{Mg}\left(\mathrm{Li}_{2}\right)-p$ DHT phase was then produced on the gram-scale by thermal annealing of $\mathrm{Mg}\left(\mathrm{Li}_{2}\right)-p-\mathrm{DHT} \cdot \mathrm{H}_{2} \mathrm{O}$ at $235^{\circ} \mathrm{C}$ for $48 \mathrm{~h}$ under ambient air, producing a khaki powder (Fig. 2c). Scanning electron microscopy (SEM) revealed agglomerations of thin micron-sized platelets which were a few tenths of a nanometer thick (Fig. 3a).

Transmission electron microscopy (TEM) imaging confirmed the rectangular shape of unbroken individual particles, of which the largest measured $2 \times 3 \mu \mathrm{m}$, and also piles of flaky particles mixed with others displaying a thin tubular morphology $(\sim 20 \mathrm{~nm}$ in diameter). The lamellar atomic structure of the materials is evidenced by its high tendency to exfoliate, crease or roll, as commonly observed for thin lamellar structures. The selectedarea electron diffraction (SAED) pattern on the individual plate points to an orthogonal symmetry of the layers $(\sim 3.3 \times 7.8 \AA)$.

Charge/discharge electrochemical testing of $\mathrm{Mg}\left(\mathrm{Li}_{2}\right)-p$-DHT vs. Li. For the sake of comparison, the electrochemical investigations were performed vs. Li in Swagelok ${ }^{\circledast}$-type cells, following a procedure similar to the one previously reported for the two $\mathrm{Li}_{4} \mathrm{DHT}$ regioisomers (i.e., simply mixing the active material with $33 \mathrm{wt} \%$ conducting carbon without binder). We started by investigating this dual-function electrode material upon oxidation (i.e., 
a

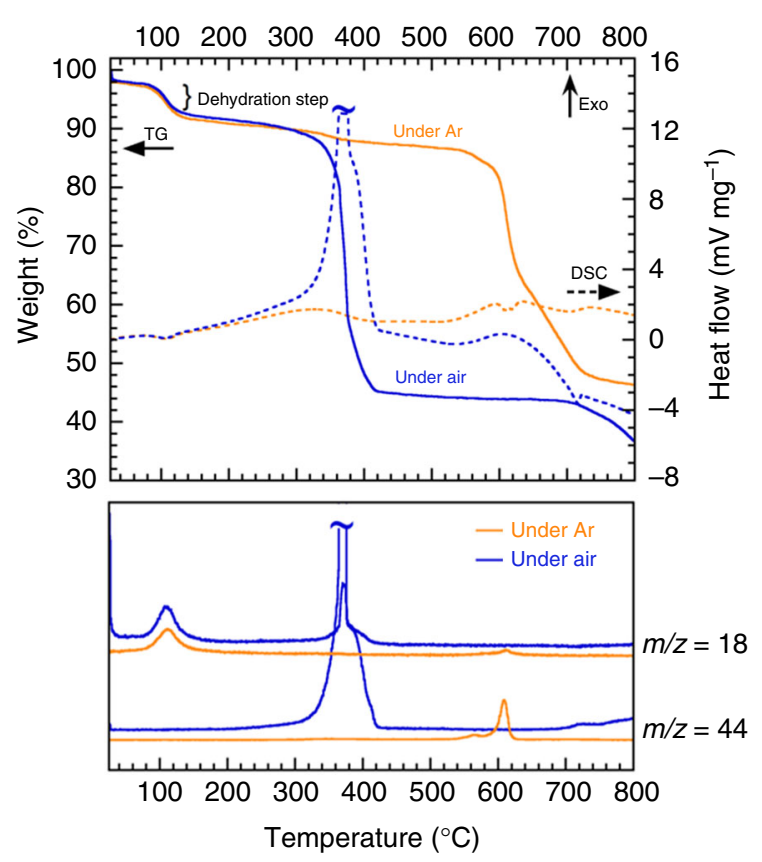

b

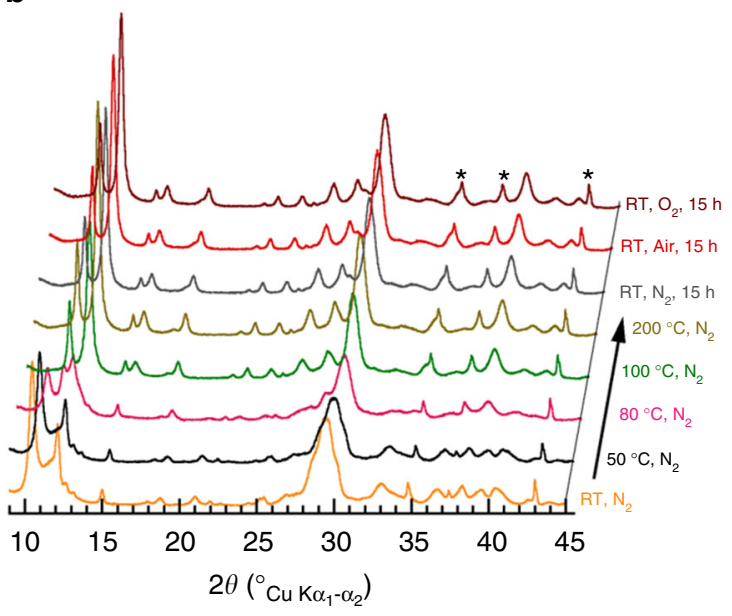

C

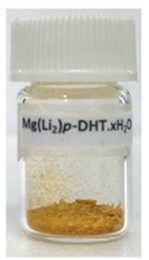

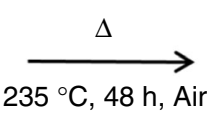

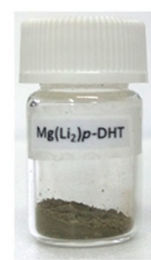

Fig. 2 Thermal properties of $\mathrm{Mg}\left(\mathrm{Li}_{2}\right)-p-\mathrm{DHT} \cdot \mathrm{H}_{2} \mathrm{O}$. a Thermogravimetry (TG) and differential scanning calorimetry (DSC) traces of $M g\left(\mathrm{Li}_{2}\right)-p-\mathrm{DHT} \cdot \mathrm{H}_{2} \mathrm{O}$ measured under argon or air flow at a heating rate of $5^{\circ} \mathrm{C} \mathrm{min}^{-1}$, combined with mass spectrometry (MS) data; $\mathrm{m} / \mathrm{z}=18$ is ascribed to $\mathrm{H}_{2} \mathrm{O}$, and 44 to $\mathrm{CO}_{2}$ evolutions, respectively. b TRXRPD patterns collected under nitrogen flow from RT to $200^{\circ} \mathrm{C}$. After an isotherm at $200{ }^{\circ} \mathrm{C}(16 \mathrm{~h})$, the sample was cooled down to $20^{\circ} \mathrm{C}$ and maintained under $\mathrm{N}_{2}$ for $15 \mathrm{~h}$ before changing the atmosphere for air, and then finally for pure $\mathrm{O}_{2}$ flow ( ${ }^{*}$ corresponds to the diffraction peak of the sample holder made of $\mathrm{Al}_{2} \mathrm{O}_{3}$ ). $\mathbf{c}$ The orange color of the pristine powder changed to a khaki color after the dehydration process at $235^{\circ} \mathrm{C}$ for $48 \mathrm{~h}$ in air
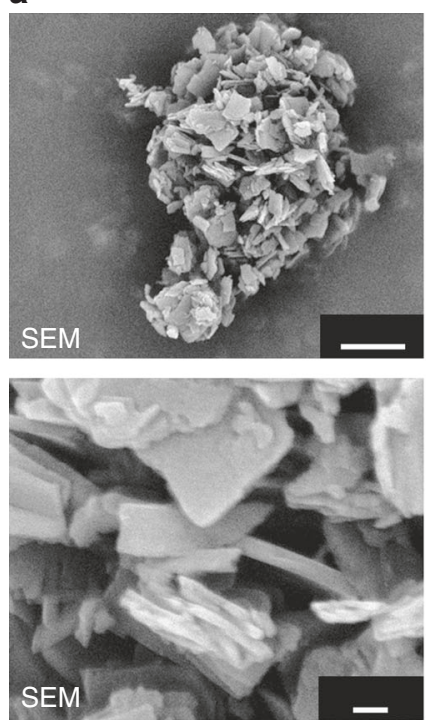

b

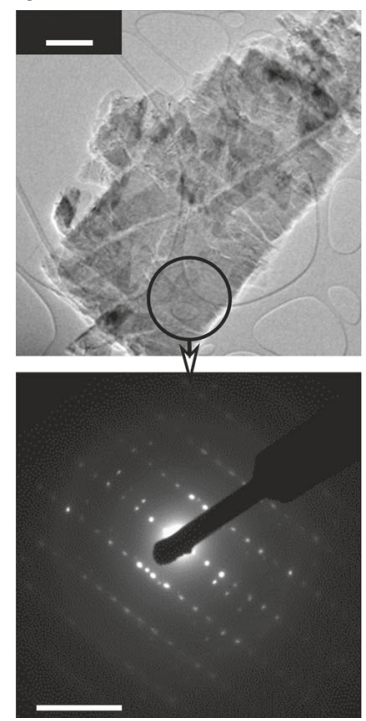

C
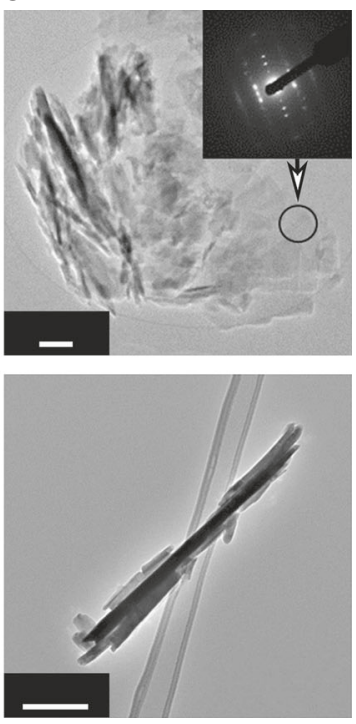

Fig. 3 Characterizations by electron microscopy techniques. a Typical SEM images obtained by means of backscattered electrons of desolvated $M g\left(\mathrm{Li}_{2}\right)-p$ DHT particles showing agglomerations of thin platelets. Scale bar represents $1 \mu \mathrm{m}$ (up) and $100 \mathrm{~nm}$ (down), respectively. b TEM image of a large platelet together with the corresponding SAED pattern, recorded from the circled zone, revealing an orthogonal 2D cell of $\sim 3.3 \times 7.8 \AA$. Additional signal comes from slightly disoriented exfoliated layers. Scale bar represents $0.5 \mu \mathrm{m}$ (up) and $5 \mathrm{~nm}^{-1}$ (down), respectively. c Additional view of the thin, partly exfoliated, creased or rolled particles, together with the same selected-area electron diffraction (SAED) pattern recorded on flat particles. Bottom: micronlong rolled particles forming a 40 -nm tube. Scale bar represents $0.2 \mu \mathrm{m}$ 

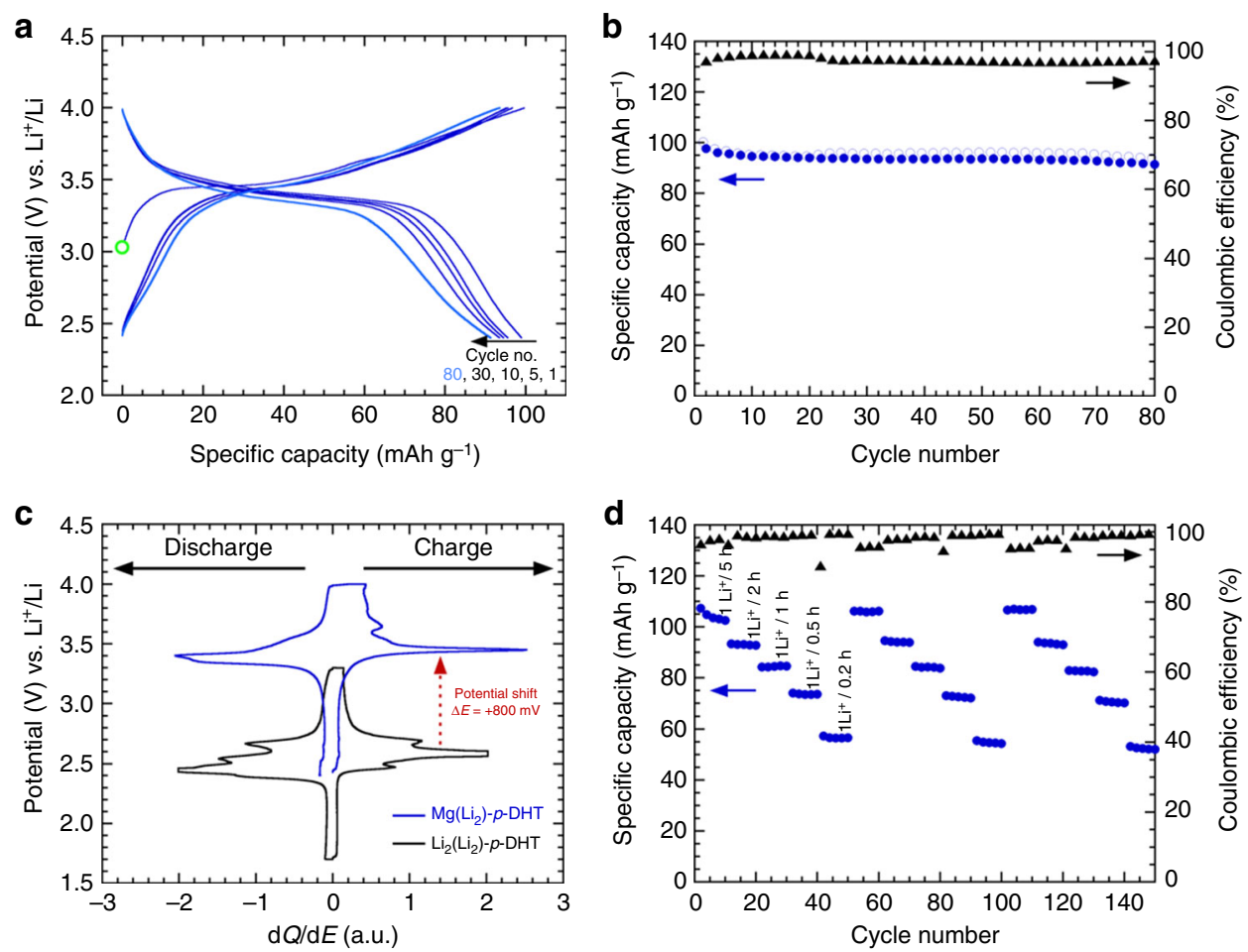

Fig. 4 Charge/discharge electrochemical performance of $\mathrm{Mg}\left(\mathrm{Li}_{2}\right)-\mathrm{p}$-DHT electrode material vs. Li. a Potential vs. specific capacity curve (cycle nos. 1, 5, 10, 30 and 80 ) of a Li half-cell using $\mathrm{Mg}\left(\mathrm{Li}_{2}\right)-\mathrm{p}$-DHT as the active electrode material, mixed with 33 wt.\% Ketjenblack EC-600JD (no binder) and galvanostatically cycled at a rate of $1 \mathrm{Li}^{+} / 5 \mathrm{~h}\left(I=23 \mathrm{~mA} \mathrm{~g}^{-1}\right) \mathrm{LiPF}_{6} 1 \mathrm{M}$ in EC/DMC as the electrolyte. Note that the green circle indicates the starting open circuit potential $\left(E_{l=0} \approx 3.1 \mathrm{~V}\right.$ vs. $\left.\mathrm{Li}^{+} / \mathrm{Li}\right)$, which is notably higher than that of $\mathrm{Li}_{4}-p-\mathrm{DHT}\left(E_{l=0} \approx 2.5 \mathrm{~V} \mathrm{vs} \text {. } \mathrm{Li}^{+} / \mathrm{Li}^{4}\right)^{47}$. b Corresponding capacity retention curve, together with the coulombic efficiency. c Superimposition of the potential vs. differential capacity curves (second cycle) for both $\mathrm{Mg}\left(\mathrm{Li}{ }_{2}\right)-\mathrm{p}$ - $\mathrm{DHT}$ (blue) and $\mathrm{Li}_{4}-\mathrm{p}$-DHT (black) cycled vs. Li. The red arrow marks the positive potential shift. $\mathbf{d}$ Specific capacity vs. cycle number for current rate changes ranging from $1 \mathrm{Li}^{+} / 5 \mathrm{~h}$ to $1 \mathrm{Li}^{+} / 0.2 \mathrm{~h}$ per series of 10 cycles (repeated three times)

operating as a positive electrode, Supplementary Fig. 1c) through the diphenolate electroactivity. Figure 4a shows the typical potential-specific capacity trace measured in galvanostatic mode, within the $2.4-4.0 \mathrm{~V}$ potential range, at a cycling rate of one $\mathrm{Li}^{+}$ exchanged per ligand in $5 \mathrm{~h}$. As expected, $\mathrm{Mg}\left(\mathrm{Li}_{2}\right)-p$-DHT behaves similarly to the two $\mathrm{Li}_{4} \mathrm{DHT}$ regioisomers by displaying an efficient reversible delithiation/lithiation process, which demonstrates the robustness of this organic chemical structure as well as its stability in carbonate-based liquid electrolytes. The most striking feature, nevertheless, is its impressively high average operating potential approaching $3.5 \mathrm{~V}$ vs. $\mathrm{Li}^{+} / \mathrm{Li}$ (Fig. 4a). This net potential gain of $+800 \mathrm{mV}$ compared to its $\mathrm{Li}_{4}-p$-DHT counterpart ${ }^{47}$ is better illustrated in Fig. $4 \mathrm{c}$ by simultaneously comparing the potential vs. differential capacity curves of $\mathrm{Mg}$ $\left(\mathrm{Li}_{2}\right)-p$-DHT and $\mathrm{Li}_{4}-p$-DHT. This outstanding result extends the series of considerations reported by Lewandowski et al. ${ }^{53}$ concerning the stabilizing effect of $\mathrm{Mg}^{2+}$ on the aromatic system to the domain of solid-state electrochemistry. Different cycling rates ranging from $1 \mathrm{Li}^{+} / 5 \mathrm{~h}$ to $1 \mathrm{Li}^{+} / 0.2 \mathrm{~h}$, repeated three times, were also applied to another $\mathrm{Mg}\left(\mathrm{Li}_{2}\right)-p$-DHT/Li half-cell in order to roughly assess the capability of the active material (Fig. $4 \mathrm{~d}$ ). It is worth noting that cycling with a stable restored capacity of almost $100 \mathrm{mAhg}^{-1}$ coupled with good coulombic efficiency was obtained, even though the design of the composite electrode architecture was not optimized. Initial capacities were systematically recovered for each current rate change, indicating that the specific capacity loss at each current increase is purely due to kinetic limitations of the electrode; in other words, $\operatorname{Mg}\left(\mathrm{Li}_{2}\right)$ - $p$ DHT does not appear to be damaged at high cycling rates. In addition, no changing in the electrochemical behavior is noted upon cycling confirming the high stability of the $\mathrm{Mg}\left(\mathrm{Li}_{2}\right)-p-\mathrm{DHT}$ electrode material (see cycle no. 1 and 80 in Fig. 4a). As expected, no exchange between $\mathrm{Mg}^{2+}$ cations chelated by carboxylate functional groups and $\mathrm{Li}^{+}$from the surrounding electrolyte is observed. Indeed, if an ion exchange reaction occurred during the cycling, then the inductive effect due to the presence of $\mathrm{Mg}^{2+}$ should disappear and the measured redox potential should decrease towards that of $\mathrm{Li}_{2}\left(\mathrm{Li}_{2}\right)$-p-DHT (i.e., $\mathrm{Li}_{4}-p$-DHT). However, an apparent electrochemical reactivity restricted to roughly half of the expected 2-electron capacity $\left(Q_{\text {th. }}=230 \mathrm{mAh}\right.$ $\mathrm{g}^{-1}$, Supplementary Fig. 1b, positive side) was measured by coulometry in the $2.4-4.0 \mathrm{~V}$ potential range, as was the case in our former studies on the two $\mathrm{Li}_{4} \mathrm{DHT}$ regioisomers ${ }^{47,51}$ which required further investigations (see below).

Evidence of the charge perturbation by cationic substitution. Having been inspired by the works of Lewandowski et al. ${ }^{53}$ wherein $\mathrm{Mg}^{2+}$ was selected as a promising spectator cation, we decided to experimentally check the occurrence of this electronic charge perturbation within our particular tetranionic ligand by comparing the behavior of $\mathrm{Mg}\left(\mathrm{Li}_{2}\right)-p$-DHT with $\mathrm{Ba}\left(\mathrm{Li}_{2}\right)-p-\mathrm{DHT}$, $\mathrm{Ca}\left(\mathrm{Li}_{2}\right)-p$-DHT and $\mathrm{Li}_{2}\left(\mathrm{Li}_{2}\right)-p$-DHT, as indicated above. Note that the preparation and related characterizations of the two latter salts are detailed in the Supporting Information section. Among the various analytical tools used by Lewandowski et al. ${ }^{53}$ to assess the electronic charge perturbation in the ligand through the $\mathrm{M}-\mathrm{O}$ bonds, FTIR spectroscopy proved to be the most suitable technique for probing solid-state electrode materials. Figure 5a displays the typical FTIR response of the three materials together, with the acid form spectrum for comparison; the typical assignment of infrared radiation (IR) vibration bands is listed in Supplementary Table 3. 
a

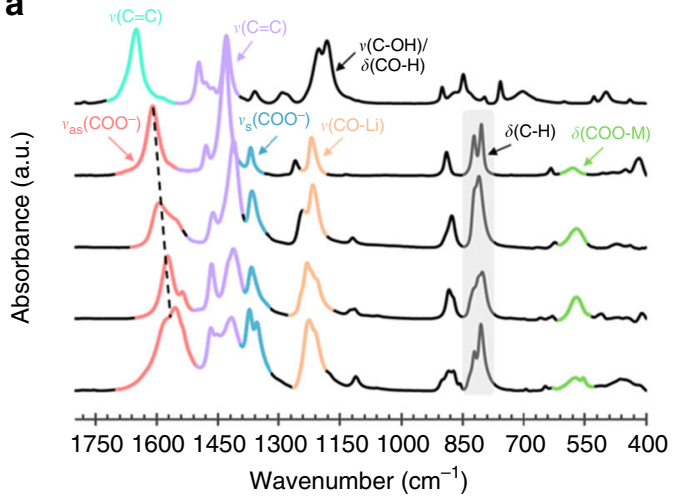

b

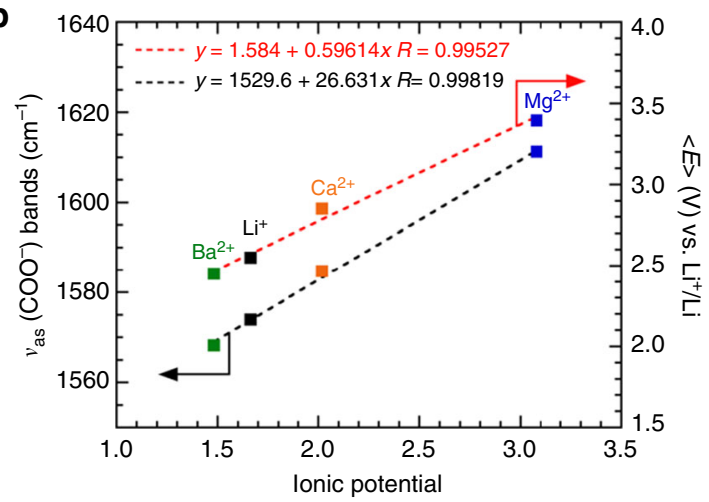

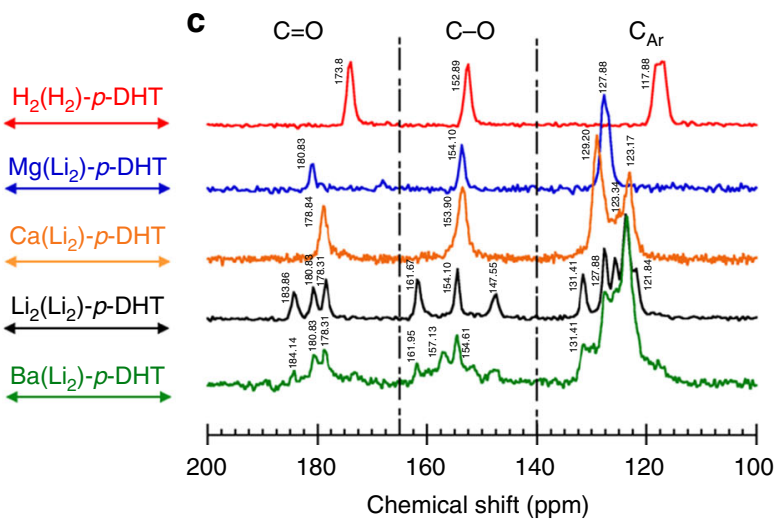

d

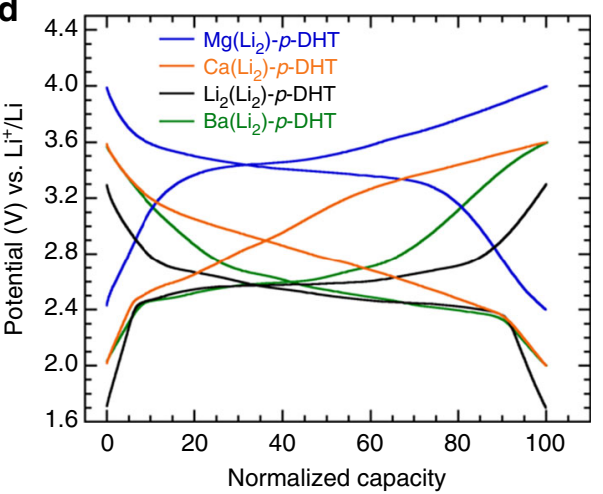

Fig. 5 Charge perturbation in $\mathrm{M}_{2 / n}^{n+}\left(\mathrm{Li}_{2}\right)$-p-DHT electrode materials $\left(\mathrm{M}^{n+}=\mathrm{Li}^{+}, \mathrm{Mg}^{2+}, \mathrm{Ca}^{2+}\right.$ and $\mathrm{Ba}^{2+}$. a Overlaid FTIR spectra of Ba( $\left.\mathrm{Li}_{2}\right)-p$-DHT (green), $\mathrm{Li}_{2}\left(\mathrm{Li}_{2}\right)-p-\mathrm{DHT}$ (black), $\mathrm{Ca}\left(\mathrm{Li}_{2}\right)-p-\mathrm{DHT}$ (orange) and $\mathrm{Mg}\left(\mathrm{Li}_{2}\right)-p-\mathrm{DHT}$ (blue), including that of the acid form of the ligand, namely $\mathrm{H}_{4}-p-\mathrm{DHT}_{\mathrm{T}}$ or $\mathrm{H}_{2}\left(\mathrm{H}_{2}\right)-p-$ $\mathrm{DHT}$ (red), for comparison. $\mathbf{b}$ Correlation between both the antisymmetric vibrational modes of the carboxylate functional groups, $\nu_{\text {as }}\left(\mathrm{COO}^{-}\right)$, and the average operating potential $\langle E\rangle$ (determined from differential capacity data) against the ionic potential of $\mathrm{M}^{n+}$. The dotted line is the linear fitting. c Overlaid ${ }^{13} \mathrm{C}$ CP MAS-NMR spectra following the same order as in $\mathbf{a}$. $\mathbf{d}$ Overlay of the as-obtained typical galvanostatic curve for each organic salt (2nd cycle) after normalization of the restored capacity (rate: $1 \mathrm{Li}^{+} / 5 \mathrm{~h}$, active material with $33 \mathrm{wt} . \%$ Ketjenblack EC-600JD; electrolyte: LiPF 6 M in EC/DMC)

For the four salts of the tetranionic $p$-DHT ligand, the deprotonation step is confirmed by the disappearance of the two characteristic bands of carboxylic acid groups located at $1648 \mathrm{~cm}^{-1}\left(v_{\mathrm{C}=\mathrm{O}}\right)$ and $1180 \mathrm{~cm}^{-1}\left(v_{\mathrm{C}-\mathrm{O}} / \delta_{\mathrm{C}-\mathrm{O}-\mathrm{H}}\right)$, respectively. Indeed, the electron density is shared equally in the carboxylate anion between the two equivalent $\mathrm{C}-\mathrm{O}$ bonds giving rise to an asymmetric mode $\left(v_{\mathrm{as}}\right)$ located in the 1550 and $1650 \mathrm{~cm}^{-1}$ regions, and a symmetric mode $\left(v_{s}\right)$ observed between 1300 and $1420 \mathrm{~cm}^{-1}$. Of these two carboxylate modes, the position of the $v_{\text {as }}\left(\mathrm{COO}^{-}\right)$band is known to be sensitive to the electron density on the carboxylate carbon ${ }^{61}$; its shift to higher wavenumbers is correlated to an electron density decrease. Interestingly, the spectrum overlay shows a strong upshift of $v_{\mathrm{as}}\left(\mathrm{COO}^{-}\right)$bands with $\mathrm{Mg}$, unlike its $\mathrm{Li}, \mathrm{Ca}$, and $\mathrm{Ba}$ counterparts (Fig. 5a, pale red bands), indicating a stronger interaction with this cation and consequently a mitigation of the $+\mathrm{I}$ effect of the carboxylate anions towards the ring (stabilization of the aromatic system). This behavior is also well supported by the upshift of the aromatic bands (Fig. 5a, purple bands). In short, this FTIR study clearly confirms the mitigation effect on the electronic charge perturbation occurring in our tetranionic ligand depending on the chemical nature of the cation $\mathrm{M}$, in accordance with the series of statements established by Lewandowski et al. ${ }^{53}$. As with these authors, one can distinctly observe a quasi-linear correlation when plotting $v_{\text {as }}\left(\mathrm{COO}^{-}\right)$against the ionic potential of $\mathrm{M}^{n+}$ (Fig. $5 \mathrm{~b}$ ).

These four organic materials were further probed in the solid state by magic-angle spinning (MAS) ${ }^{13} \mathrm{C}$ NMR (Fig. 5c). Essentially, the spectra can be divided into three regions displaying characteristic resonances assigned to (COO) (from
178 to184 ppm), to $(\mathrm{CO})$ (from 147 to $162 \mathrm{ppm})$ and to $\left(\boldsymbol{C}_{\mathrm{Ar}}\right)$ carbons (121 to $132 \mathrm{ppm})$. As already observed for the IR spectra of $\mathrm{Li}_{2}\left(\mathrm{Li}_{2}\right)-p$-DHT and $\mathrm{Ba}\left(\mathrm{Li}_{2}\right)-p$-DHT (Fig. 5a), their NMR counterparts also present striking similarities, displaying three resonances in the $(\mathrm{COO})$ and $(\mathrm{CO})$ regions as well as a group of five overlapping resonances, all of which showing very similar chemical shifts. These complex NMR spectra particularly point to non-symmetric molecules with non-equivalent carbon atoms, as well as an identical overall configuration for these two compounds. Contrarily, the $\mathrm{Ca}\left(\mathrm{Li}_{2}\right)-p-\mathrm{DHT}$ and $\mathrm{Mg}\left(\mathrm{Li}_{2}\right)-p$ DHT ${ }^{13} \mathrm{C}$ CP MAS-NMR spectra are more straightforward with only one resonance in each $(\mathrm{COO})$ and $(\mathrm{CO})$ region and two resonances (strongly overlapping in the case of $\mathrm{Mg}\left(\mathrm{Li}_{2}\right)-p-\mathrm{DHT}$ ) in the $C_{\mathrm{Ar}}$ region, which is indicative of a higher symmetry of the molecule, in agreement with the corresponding FTIR spectrum. The clear evolution observed in FTIR and electrochemical analyses from $\mathrm{Ba}\left(\mathrm{Li}_{2}\right)-p$-DHT, $\mathrm{Li}_{2}\left(\mathrm{Li}_{2}\right)-p$-DHT and $\mathrm{Ca}\left(\mathrm{Li}_{2}\right)-p$ DHT to $\mathrm{Mg}\left(\mathrm{Li}_{2}\right)-p$-DHT can therefore also be monitored with NMR. We expected the effect of the electronegativity of the countercation on the ${ }^{13} \mathrm{C}$ NMR chemical shift to be more visible on the most shielded carbons (i.e., those with the lowest chemical shifts), as is usually the case with the true electroactive center related to the redox-active phenolate functional group. At this point, it should be recalled that the hybrid shown in Fig. 1 exhibits a higher electron density for the $\mathrm{C}(3)$ and $\mathrm{C}(6)$ carbon atoms. Since $\mathrm{Mg}$ is more electronegative, its attractive effect can clearly be observed where it is easier to pull electrons out. Where $\mathrm{Ba}\left(\mathrm{Li}_{2}\right)-p-\mathrm{DHT}, \mathrm{Li}_{2}\left(\mathrm{Li}_{2}\right)-p-\mathrm{DHT}$ and $\mathrm{Ca}\left(\mathrm{Li}_{2}\right)-p-\mathrm{DHT}$ are concerned, the most shielded aromatic carbons appear at 121.8, 
a

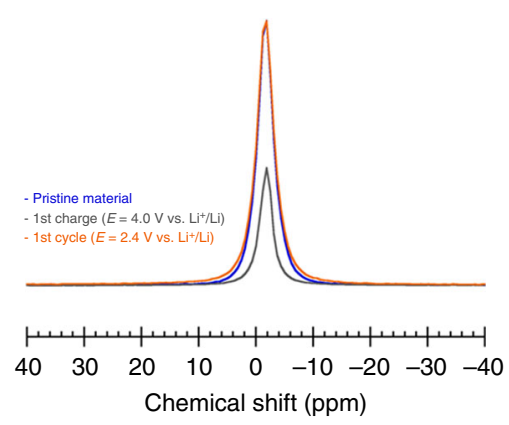

b

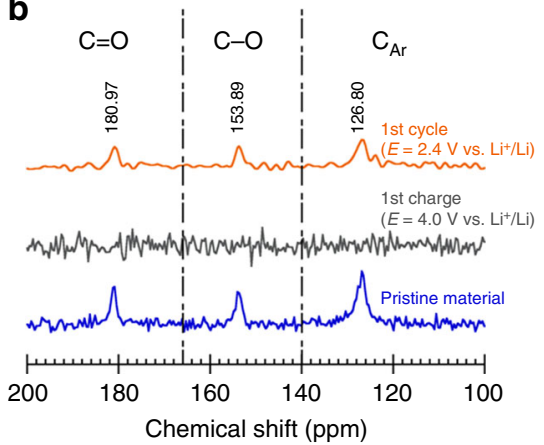

C

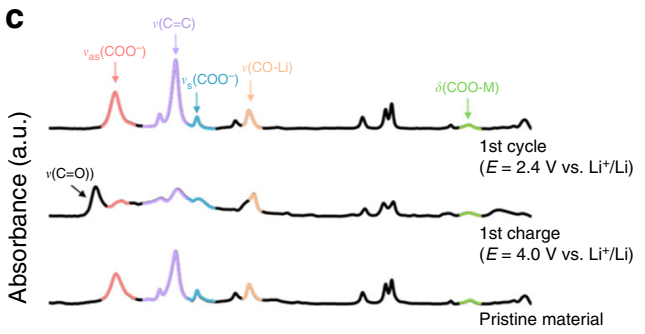

$18001600140012001000 \quad 800 \quad 600 \quad 400$

d
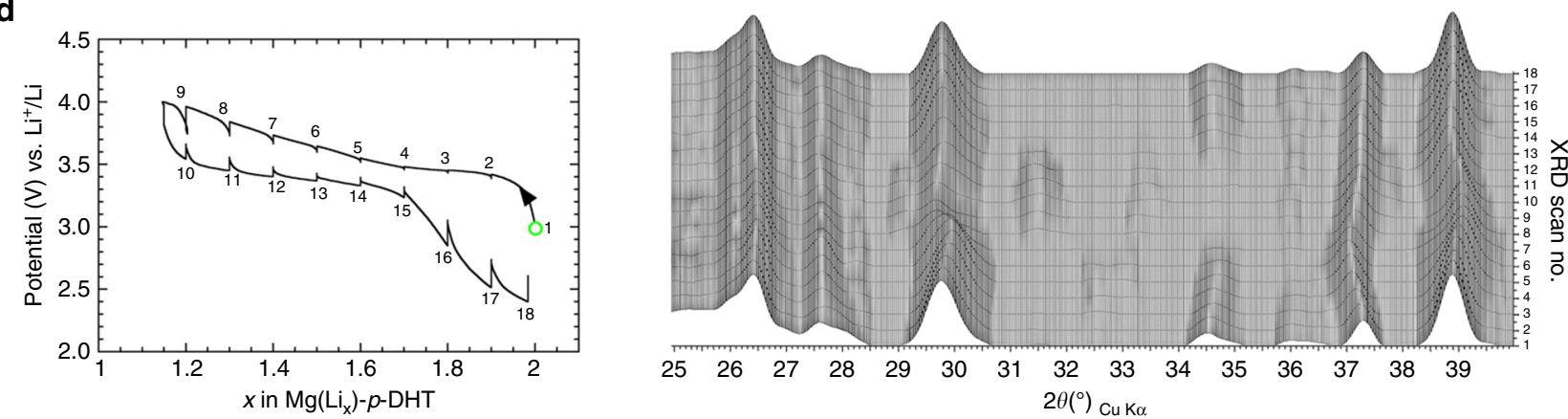

Fig. 6 Supporting data for one-electron limited electrode process. a Ex situ ${ }^{7}$ Li MAS-NMR spectra. b Corresponding ex situ ${ }^{13} \mathrm{C}$ CP MAS-NMR spectra using micrometric-sized Pt particles in place of carbon black conducting additive. $\mathbf{c}$ FTIR data for $\mathrm{Mg}\left(\mathrm{Li}{ }_{2}\right)-\mathrm{p}$-DHT-based electrodes containing 33 wt.\% Ketjenblack EC-600JD before cycling (blue), after a first charge up to $4 \mathrm{~V} \mathrm{vs.} \mathrm{Li}^{+} / \mathrm{Li}$ (gray) and one full cycle (orange), within the $2.4-4.0 \mathrm{~V}$ potential range (rate: $1 \mathrm{Li}^{+} / 5 \mathrm{~h}$ ). d Potential-composition profile for a $\mathrm{Mg}\left(\mathrm{Li}_{2}\right)-\mathrm{p}$-DHT/Li in situ XRD electrochemical cell63 together with the corresponding collected XRD patterns over the $10-40^{\circ} 2 \theta$ range. The cell was cycled in the $2.4-4.0 \mathrm{~V}$ potential range using an intermittent galvanostatic mode. More specifically, a current of $11.2 \mathrm{~mA}$ per $\mathrm{g}$ of $\mathrm{Mg}\left(\mathrm{Li}_{2}\right)-\mathrm{p}-\mathrm{DHT}$ (rate: $1 \mathrm{Li}+/ 10 \mathrm{~h}$ ) was applied for a period of $2 \mathrm{~h}$, separated by resting periods of $1 \mathrm{~h}$ during which the XRD patterns were collected (electrolyte: $\mathrm{LiPF}_{6} 1 \mathrm{M}$ in EC/DMC)

$123.3 \mathrm{ppm}$ and $123.2 \mathrm{ppm}\left(\boldsymbol{C}_{\mathrm{Ar}}\right)$, in agreement with their electronegativity values of the same order of magnitude (Supplementary Table 1). The corresponding resonance appears at $127.9 \mathrm{ppm}$ when $\mathrm{Li}^{+}, \mathrm{Ba}^{2+}$ or $\mathrm{Ca}^{2+}$ are replaced with $\mathrm{Mg}^{2+}$, consistent with its notably higher electronegativity value $(\chi=1.29$ based on the Allred-Rochow scale). Therefore, $\delta\left(\boldsymbol{C}_{\mathrm{Ar}}\right)$ appears to be the appropriate NMR parameter here-although it appears to be somewhat less sensitive with respect to the variations of $v_{\mathrm{C}=\mathrm{O}}$ and $v_{\mathrm{C}=\mathrm{C}}$ in FTIR spectra-in order to monitor the influence of the $\mathrm{M}-\mathrm{O}$ bonds on the distribution of p-electron density in the aromatic ring, by mitigating the donor inductive effects of the $-\mathrm{COO}^{-}$group in particular. Indeed, although the larger difference in electronegativity values and electrochemical potentials between $\mathrm{Ba}\left(\mathrm{Li}_{2}\right)-p$-DHT, $\mathrm{Li}_{2}\left(\mathrm{Li}_{2}\right)-p$-DHT and $\mathrm{Ca}\left(\mathrm{Li}_{2}\right)-p$ DHT on one hand and $\left.\mathrm{Mg}\left(\mathrm{Li}_{2}\right)-p-\mathrm{DHT}\right)$ on the other hand translates in a significant difference in terms of chemical shifts, the smaller difference observed between cases of $\mathrm{Ba}\left(\mathrm{Li}_{2}\right)-p$-DHT, $\mathrm{Li}_{2}\left(\mathrm{Li}_{2}\right)$ - $p$-DHT and $\mathrm{Ca}\left(\mathrm{Li}_{2}\right)-p$-DHT is barely observed in terms of their respective chemical shift. Finally, we decided to go a step beyond the works of Lewandowski et al. ${ }^{53}$ by also trying to correlate the average operating potential $\langle E\rangle$ (Fig. $5 \mathrm{~d}$ ) of each salt to the ionic potential of $\mathrm{M}^{n+}$, and managed to obtain a very good linear fit (Fig. 5b). To our knowledge, this is the first time that such a correlation is being reported.

Ex situ and in situ characterizations of the one-electron limited electrochemical process. As stated above, in our experimental conditions, all coulometry measurements performed on $M_{2 / n}^{n+}\left(\mathrm{Li}_{2}\right)--p$-DHT electrode materials $\left(\mathrm{M}=\mathrm{Li}^{+}, \mathrm{Mg}^{2+}, \mathrm{Ca}^{2+}\right.$ and $\left.\mathrm{Ba}^{2+}\right)$ systematically indicated a peculiar reversible process restricted to a one-electron reaction, although a very good performance was shown upon cycling (see ref. ${ }^{53}$ for $\mathrm{M}^{n+}=\mathrm{Li}^{+}$, Fig. 5 for $\mathrm{M}^{n+}=\mathrm{Mg}^{2+}$, Supplementary Fig. 5 for $\mathrm{M}^{n+}=\mathrm{Ba}^{2+}$, Supplementary Fig. 6 for $\mathrm{M}^{n+}=\mathrm{Ca}^{2+}$ ). Interestingly, Chen and colleagues ${ }^{48,49}$ overcame this experimental factor with $\mathrm{Li}_{2}\left(\mathrm{Li}_{2}\right)-p$ DHT by synthesizing the material in the form of nanosheets. It appeared to be necessary, however, to confirm our results by employing further analytical techniques. First, ${ }^{7} \mathrm{Li}$ MAS-NMR was chosen as a powerful quantitative method for monitoring the amount of lithium ions involved in the redox and electrochemical reactions, since the integrated intensity of the acquired signal is directly proportional to the amount of nuclei under observation in the sample ${ }^{62}$. In the present case, we opted for a normalization of integrated intensities for the sake of simplicity, using 2 and 4 values for the pristine $\mathrm{Mg}\left(\mathrm{Li}_{2}\right)-p$-DHT (Fig. 6a) and $\mathrm{Li}_{2}\left(\mathrm{Li}_{2}\right)-p$ DHT (Supplementary Fig. 6a) composite electrodes, respectively. Integrated intensities for the $\mathrm{Li}_{2}\left(\mathrm{Li}_{2}\right)$ - $p$-DHT electrode after the 1st charge (oxidation), and after one cycle (subsequent reduction), were 3.1 and 4.1 , respectively, supporting the fact that only one $\mathrm{Li}^{+} /$ring reacts. However, caution should be exercised with respect to this overall value because some particles may not be reacting. In the hypothesis of an incomplete electrical percolation within the composite electrode leading to the disconnection of exactly half of the active particles, the signature of the pristine (unreacted) $\mathrm{Li}_{2}\left(\mathrm{Li}_{2}\right)$ - $p$-DHT material would certainly be detected by ${ }^{13} \mathrm{C}$ NMR after oxidation. However, there was neither a trace of the pristine compound detected at the end of oxidation nor a trace of the oxidized compound observed after one charge-discharge cycle (Supplementary Fig. 6b). Similarly, for Mg $\left(\mathrm{Li}_{2}\right)$-p-DHT (Fig. 6a), integrated intensities after one oxidation and after one cycle were 1.2 and 2.2, respectively, again 
supporting the occurrence of a one-electron reaction. In addition to this, ${ }^{13} \mathrm{C}$ CP MAS-NMR experiments were also performed with $\mathrm{Mg}\left(\mathrm{Li}_{2}\right)-p$-DHT, although the low signal to noise ratio did not permit the acquisition of exploitable data due to the presence of conductive carbon within the electrode. With the purpose of facilitating the observation of the natural abundance ${ }^{13} \mathrm{C}$ signal, without it being hindered by the ${ }^{13} \mathrm{C}$ NMR signal stemming from the carbon additive (Supplementary Fig. 6b), we developed a novel electrode formulation wherein the carbon additive was replaced with Pt micrometric-sized particles to ensure electronic conductivity within the composite electrode. To the best of our knowledge, an electrode formulation of this type has never been used before, and has proven to be invaluable for monitoring the ${ }^{13} \mathrm{C}$ CP MAS-NMR evolution upon cycling. Spectra corresponding to $\mathrm{Mg}\left(\mathrm{Li}_{2}\right)-p$-DHT after one oxidation and one cycle (Fig. 6b) clearly indicate that the pristine material is recovered after one full electrochemical cycle. The absence of signal for the oxidized material could be assigned to the formation of the radical form of the active organic material $(\mathrm{Mg}(\mathrm{Li})-p-\mathrm{DHT})^{*}$, thereby inducing an extremely short NMR signal relaxation time, and thus leading to an extremely broad resonance which is unobservable under fast MAS, even in low field conditions. Moreover, the formation of a radical form of the material supports the one-electron reaction. Therefore, the combined ${ }^{7} \mathrm{Li}$ and ${ }^{13} \mathrm{C}$ NMR results unambiguously indicate that only one $\mathrm{Li}^{+} /$ring is reversibly involved in the overall electrochemical reaction. The slight variation in terms of the integrated intensity observed for the cycled samples could either be ascribed to $\mathrm{Li}$ in the passivation layer on the surface of the electrode or to remaining unreacted $\mathrm{LiPF}_{6}$ salt from the electrolyte. Additionally, the reversibility of the electrochemical reaction was assessed by means of ex situ FTIR measurements during the first cycle (Fig. 6c). Upon oxidation, FTIR data revealed a reversible process with the emergence of a new band at $\sim 1700 \mathrm{~cm}^{-1}$, which can be assigned to the carbon-oxygen stretching bands of the quinone or semiquinone radical groups. However, the slight alteration of $v_{\mathrm{as}}\left(\mathrm{C}-\mathrm{O}^{-}\right)$bands at $\sim 1250 \mathrm{~cm}^{-1}$ seems to confirm the formation of a semiquinone radical since no bands are expected to appear in this region if the quinone form of the ligand is produced ${ }^{48}$. Finally, in situ XRD measurements (Fig. 6d) clearly emphasize the reversibility of the electrode reaction in the solid state. The relatively sharp Bragg peak at $39.3^{\circ}$ broadens and shifts progressively towards higher angles at $39^{\circ}$ upon the one-electron oxidation. The subsequent reduction sees the same Bragg peak sharpening and returning to its initial position.

By way of summary, coulometric measurements, combined ${ }^{7} \mathrm{Li}$ and ${ }^{13} \mathrm{C}$ NMR data, as well as FTIR spectroscopy, confirm the occurrence of a one-electron reaction per ring in all three representative salts, thus illustrating the fact that the electrochemical reaction seems to occur reversibly between $M_{2 / n}^{n+}\left(\mathrm{Li}_{2}\right)-p$-DHT and $M_{2 / n}^{n+}(\mathrm{Li})-p$-DHT (radical) without reaching full oxidation into the quinone form (Supplementary Fig. 1c, positive side). Interestingly, a parallel can be drawn here with the p-type poly(vinylphenothiazine) electrode material reported by Esser and colleagues ${ }^{17}$, which enables a specific capacity that is also half of the theoretical one. In their study, the reversible reaction occurs between the radical cation and the cationic states, without restoring the original neutral state of the pristine polymer; a symmetrical situation occurs in our n-type electroactive system. The authors explained this incomplete electrode reaction as being the result of a peculiar stabilizing effect due to intra-chain or inter-molecular $\pi-\pi$ interactions between phenothiazine units. This situation may well also apply to our lamellar organic scaffold. Chen and colleagues ${ }^{48,49}$ succeeded in obtaining the full theoretical capacity with $\mathrm{Li}_{2}\left(\mathrm{Li}_{2}\right)-p$-DHT, perhaps because the stacking height of a pile is significantly decreased in nanosheets and thereby alters the stabilizing $\pi-\pi$ interactions.

Based on this encouraging outcome, it seemed relevant to conclude this study by assembling an all-organic symmetric Liion cell, since $\mathrm{Mg}\left(\mathrm{Li}_{2}\right)-p$-DHT was also expected to function as negative electrode material through the dicarboxylate functional groups (Supplementary Fig. 1b, c). Figure 7a summarizes the stable electrochemical profile obtained from the second cycle at low potential in a Li half-cell due to the electrochemical activity of the carboxylate functional groups. The first discharge curve exhibits the common extra-capacity observed with carboxylatebased organic electrodes ${ }^{29,48,54-56}$ together with an average operating potential of $\sim 0.8 \mathrm{~V}$ vs. $\mathrm{Li}^{+} / \mathrm{Li}$ similar to the one observed with the dilithium terephthalate parent compound ${ }^{46}$. Therefore, the chemical nature of the spectator cation $\left(\mathrm{M}^{n+}\right)$ seems to particularly influence the formal potential of the diphenolate ring and not that of the attached redox-active carboxylate moieties. Interestingly, several studies have also reported this stable operating potential with various alkali and alkaline-earth metal salts of terephthalate during the reversible lithiation/delithiation electrochemical process ${ }^{64-66}$. Without optimization, a reversible insertion/uptake of $1.35 \mathrm{Li}^{+}$per formula unit can be achieved leading to specific capacity value of $157 \mathrm{mAh} \mathrm{g}^{-1}$. After 20 cycles (Fig. 7b), this composite electrode was transferred to a 3-electrode cell and used as negative electrode. The positive electrode consisted of a fresh $\mathrm{Mg}\left(\mathrm{Li}_{2}\right)-p-$ DHT-based composite (mixed with 25 wt.\% Ketjenblack EC$600 J \mathrm{D})$ acting as the positive electrode; $\mathrm{Li}$ was used as the reference electrode. Figure $7 \mathrm{c}$ shows the corresponding cycling curve exhibiting an interesting average output voltage of $2.5 \mathrm{~V}$ consecutive to the mitigation of the inductive effects in the organic scaffold, via $\mathrm{Mg}^{2+}$ for the positive side. For comparison, Chen and colleagues ${ }^{48,49}$ reported a value of $1.8 \mathrm{~V}$ for the symmetric Li-ion cell based on $\mathrm{Li}_{2}\left(\mathrm{Li}_{2}\right)-p$-DHT. Finally, Fig. $7 \mathrm{~d}$ exhibits the corresponding capacity retention curve calculated on the basis of the mass of the active material contained in the positive electrode and for different cycling rates. After 300 cycles, $82 \%$ of the initial capacity is still obtained.

\section{Discussion}

In this study, we have demonstrated that an outstanding potential increase can be achieved in solid carboxyphenolate salts by mitigating donor inductive effects in the organic core thanks to the presence of spectator cations within the host structure exhibiting high ionic potential (or electronegativity). Thus, substituting magnesium (2,5-dilithium-oxy)-terephthalate for lithium (2,5-dilithium-oxy)-terephthalate enables a net voltage gain of nearly $+800 \mathrm{mV}$ during the reversible delithiation/ lithiation electrode process-the formal redox-active organic skeleton remaining unchanged. It must be emphasized that this phenomenon, which involves subtle electrostatic effects within the chemical scaffold, should not be confused with the common potential shift related to a complexation reaction between a redox-active organic anion and a mobile cation coming from the electrolyte; the potential shift being proportional to the strength of the anion-cation pairing ${ }^{67}$. To a certain extent this finding is akin to the renowned "inductive effect" described by Goodenough and coworkers ${ }^{68,69}$ regarding the tuning of the $\mathrm{Fe}^{3+} / \mathrm{Fe}^{2+}$ redox potential in NASICON-type structures of the general formula $\mathrm{A}_{x} \mathrm{Fe}_{2}\left(\mathrm{XO}_{4}\right)_{3}$, depending on the chemical nature of the polyanion $\mathrm{XO}_{4}{ }^{n-}$. The inductive effect of the polyanion, which depends on the electronegativity of $\mathrm{X}$, weakens or strengthens the covalency of the $\mathrm{Fe}-\mathrm{O}$ bonds and thereby changes the operating potential $^{70}$. In our case the situation is simply reversed, since the redox center is the anion and not the cation. Based on several 

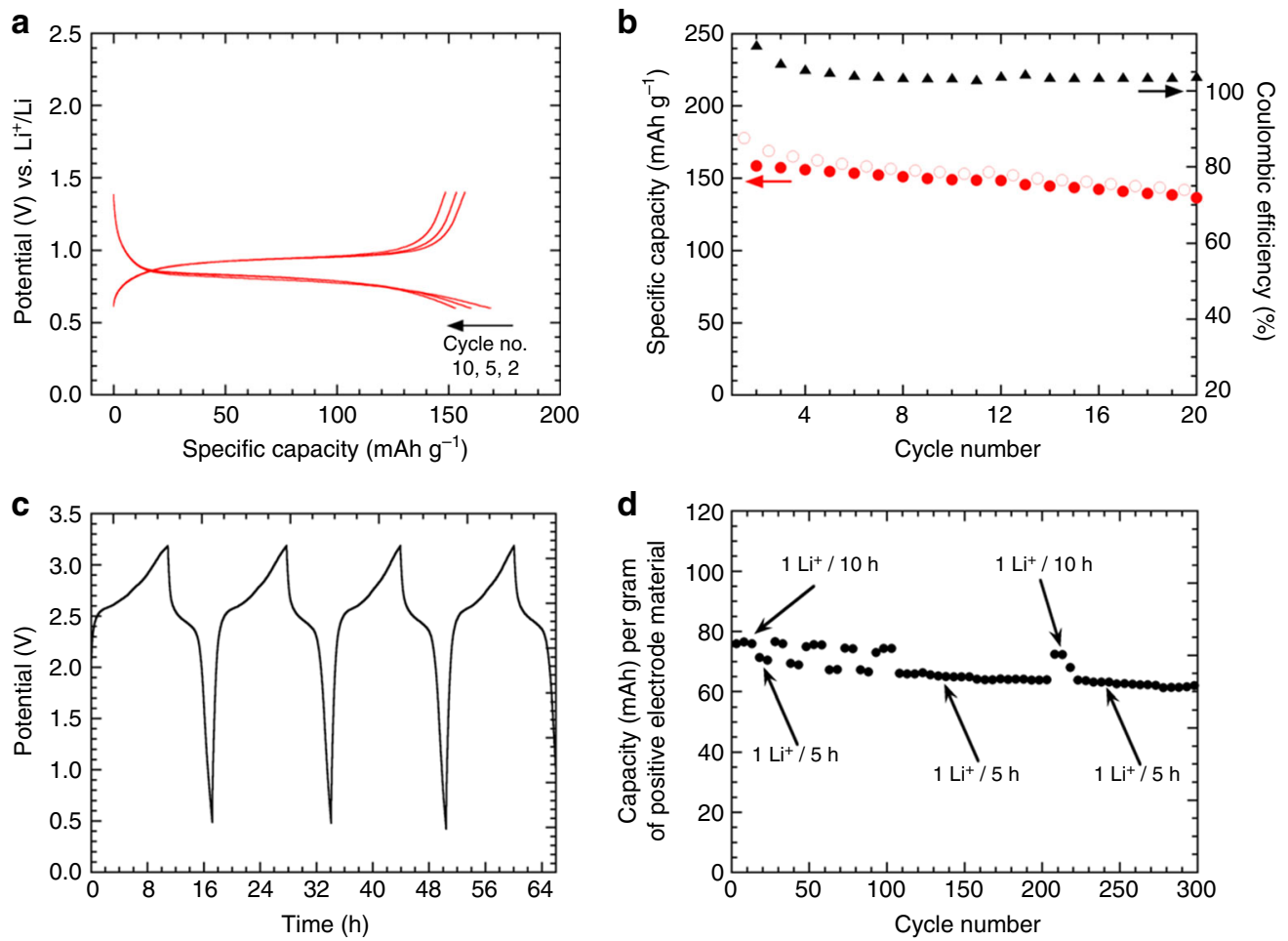

Fig. 7 All-organic symmetric Li-ion cell based on $\mathrm{Mg}\left(\mathrm{Li}_{2}\right)-p-\mathrm{DHT}$. a Potential vs. specific capacity curve (cycle nos. 2, 5 and 10) of a $\mathrm{Li}$ half-cell using Mg $\left(\mathrm{Li}_{2}\right)-\mathrm{p}$-DHT as the active electrode material, mixed with $33 \mathrm{wt} . \% \mathrm{GM} 15$ (no binder) and galvanostatically cycled at a rate of $1 \mathrm{Li}^{+} / 5 \mathrm{~h}(I=11.5 \mathrm{~mA} \mathrm{~g}-1)$ in the 0.6-1.4 V potential range using $\mathrm{LiPF}_{6} 1 \mathrm{M}$ in EC/DMC as the electrolyte. $\mathbf{b}$ Corresponding capacity retention curve. $\mathbf{c}$ Charge-discharge profile of the symmetric Li-ion cell made of $\mathrm{Mg}\left(\mathrm{Li}_{2}\right)-p-\mathrm{DHT}$ with a ratio of 1:1 showing an output voltage of $2.5 \mathrm{~V}\left(I=11.5 \mathrm{mAg} \mathrm{g}^{-1}\right.$ based on the weight of $\mathrm{Mg}\left(\mathrm{Li}_{2}\right)-p-\mathrm{DHT}$ contained in the positive electrode). $\mathbf{d}$ Specific capacity vs. cycle number for current rate changes ranging from $1 \mathrm{Li}^{+} / 10 \mathrm{~h} \mathrm{to} 1 \mathrm{Li}^{+} / 5 \mathrm{~h}$

characterization techniques, this study was also the occasion to underline (i) the good electrochemical performance of $\mathrm{Mg}\left(\mathrm{Li}_{2}\right)-p$ DHT for use as a positive lithiated electrode material, giving rise to a stable capacity retention of $\sim 100 \mathrm{Ah} \mathrm{g}^{-1}$ over several dozen cycles $\left(340 \mathrm{Wh} \mathrm{kg}^{-1}\right)$, (ii) a clear limitation at half of the theoretical capacity (one-electron reaction per ring), which is probably due to stronger stabilizing effects in the radical anion state, and (iii) the demonstration of an all-organic symmetric Li-ion cell showing $2.5 \mathrm{~V}$ as output voltage giving rise to an energy density of about $89 \mathrm{Wh}$ per $\mathrm{kg}$ of active electrode materials. Ongoing investigations using computational methods are in progress to better understand these distinctive results.

\section{Methods}

Synthesis. The synthetic protocols of the series of compounds reported in this study, as well as the common characterization techniques used (e.g., thermal and multi-elemental analyses, FTIR, liquid NMR, XRD, SEM-TEM), are thoroughly explained in supplementary information section.

Electrochemistry. For the sake of comparison, electrochemical investigations were performed in Swagelok -type cells, according to a procedure similar to the one previously reported for the two regioisomers $\mathrm{Li}_{4} \mathrm{DHT}^{47,51}$, using a $\mathrm{Li}$ metal disc as the negative electrode and a glassfiber separator soaked with $\mathrm{LiPF}_{6} 1 \mathrm{M}$ in ethylene carbonate/dimethyl carbonate (EC/DMC; 1:1 vol./vol.) as the electrolyte ( $V \sim 600$ $\mu \mathrm{L})$. The composite positive electrode was prepared without a binder in an argonfilled glovebox by grinding the powder of the active organic materials and carbon additive with a mortar and pestle; the carbon content of the final electrode being $33 \%$ in mass. For the symmetric cell measurements, a Swagelok ${ }^{\oplus}$-type 3 -electrode cell was employed using Li metal as the reference electrode. Prior to assembling the symmetric cell, the negative electrode material was first pre-cycled in the 1.4-0.6 V vs. $\mathrm{Li}^{+} / \mathrm{Li}$ potential range, until having achieved a satisfactory stability upon cycling coupled with a coulombic efficiency value close to $100 \%$ (i.e., 20 cycles, rate: $1 \mathrm{Li}$ $+/ 10 \mathrm{~h}, I=11.5 \mathrm{~mA} \mathrm{~g}^{-1}$, Fig. $\left.7 \mathrm{a}\right)$, as is reported in the literature ${ }^{48}$. The negative electrode composition was 63 wt. $\% \mathrm{Mg}\left(\mathrm{Li}_{2}\right)-p$-DHT, 32 wt.\% graphite nanoplatelets
(GM15) and 5 wt.\% PTFE, whereas the positive electrode composition was $70 \mathrm{wt} . \%$ $\mathrm{Mg}\left(\mathrm{Li}_{2}\right)$-p-DHT, 25 wt.\% Ketjenblack EC-600JD and 5 wt.\% PTFE. Each composite electrode was pressed at 1 ton $\mathrm{cm}^{-2}$ on a stainless steel (AISI 316L) grid current collector. An excess of $30 \%$ in capacity was used for the negative electrode to balance the 3-electrode cell (Fig. 7b). The positive side was controlled between 2.4 and $4 \mathrm{~V}$ vs. $\mathrm{Li}^{+} / \mathrm{Li}$, whereas the negative side was controlled between 0.6 and $1.4 \mathrm{~V}$ vs. $\mathrm{Li}^{+} / \mathrm{Li}$. All cells were cycled in galvanostatic mode using a MPG-2 multichannel system (Bio-Logic SAS, Claix, France).

MAS-NMR investigations. The solid-state MAS-NMR spectra of all studied compounds were acquired on a Bruker Avance 500 spectrometer $\left(B_{0}=11.8 \mathrm{~T}\right)$ using R.F. pulses at Larmor frequencies of $500,194.0$ and $125.7 \mathrm{MHz}$ for ${ }^{1} \mathrm{H},{ }^{7} \mathrm{Li}$ and ${ }^{13} \mathrm{C}$, respectively. The samples were packed in $2.5 \mathrm{~mm}$ diameter zirconia rotors for ${ }^{1} \mathrm{H} \rightarrow{ }^{13} \mathrm{C} \mathrm{CP}$ MAS-NMR and spun at $10 \mathrm{kHz}$. ${ }^{7} \mathrm{Li}$ NMR was performed at a spinning rate of $25 \mathrm{kHz}$ with a $90^{\circ}$ pulse length of $1.4 \mathrm{~ms}$. Long recycle times of $60 \mathrm{~s}$ were used in order to avoid saturation of the signal and to measure quantitative results. For ex situ ${ }^{7} \mathrm{Li} /{ }^{13} \mathrm{C}$ MAS-NMR (as well as for ex situ FTIR), the positive composite electrode was prepared by mixing a powder of $\mathrm{Mg}\left(\mathrm{Li}_{2}\right)-p$-DHT or $\mathrm{Li}_{2}\left(\mathrm{Li}_{2}\right)$-p-DHT (66 wt.\%) with carbon black (33 wt.\%) (typically, Ketjenblack EC$600 \mathrm{JD}$ from AkzoNobel) and cycled in galvanostatic mode at a typical rate of one lithium ion exchanged per ring in $5 \mathrm{~h}$. For ex situ ${ }^{13} \mathrm{C}$ CP MAS-NMR experiments performed on the $\mathrm{Mg}\left(\mathrm{Li}_{2}\right)-p$-DHT electrodes, the cathode was prepared by grinding a powder of $\mathrm{Mg}\left(\mathrm{Li}_{2}\right)-p$-DHT (15 wt.\%) and platinum (85 wt.\%) with a mortar and pestle. The platinum powder (amorphous) was purchased from Alfa Aesar (APS $<3 \mu \mathrm{m}, 99.9 \%$, tap density $0.6-2.0 \mathrm{~g} \mathrm{~cm}^{-3}$ ). The completed electrode was then cycled in galvanostatic mode at a rate of one lithium ion exchanged per ring in $50 \mathrm{~h}$. After cycling, the Swagelok-type cells were disassembled in glovebox. For each cell, the positive electrode was collected and rinsed repeatedly with DMC and finally dried under vacuum at $60{ }^{\circ} \mathrm{C}$ for $5 \mathrm{~h}$. The obtained samples (pristine, after one charge and one discharge) were then analyzed by ${ }^{7} \mathrm{Li}$ MAS-NMR, ${ }^{13} \mathrm{C}$ MAS-NMR, ${ }^{13} \mathrm{C}$ CP MAS-NMR and FTIR spectroscopies.

\section{Data availability}

The data supporting the findings of this study are available from the corresponding author on reasonable request. 
Received: 26 April 2018 Accepted: 24 September 2018

Published online: 23 October 2018

\section{References}

1. Tarascon, J.-M. Key challenges in future Li-battery research. Philos. Trans. R. Soc. Math. Phys. Eng. Sci. 368, 3227-3241 (2010).

2. Poizot, P., Dolhem, F., Gaubicher, J. \& Renault, S. in Lithium Process Chemistry: Resources, Extraction, Batteries, and Recycling (eds Swiatowska, J. \& Chagnes, A.)191-232 (Elsevier, Amsterdam, 2015).

3. Choi, J. W. \& Aurbach, D. Promise and reality of post-lithium-ion batteries with high energy densities. Nat. Rev. Mater. 1, 16013 (2016).

4. Bruce, P. G., Freunberger, S. A., Hardwick, L. J. \& Tarascon, J.-M. Li-O 2 and Li-S batteries with high energy storage. Nat. Mater. 11, 19-29 (2012).

5. Ji, X., Lee, K. T. \& Nazar, L. F. A highly ordered nanostructured carbon-sulphur cathode for lithium-sulphur batteries. Nat. Mater. 8, 500-506 (2009).

6. Peng, H.-J., Huang, J.-Q., Cheng, X.-B. \& Zhang, Q. Review on high-loading and high-energy lithium-sulfur batteries. Adv. Energy Mater. 7, 1700260 (2017).

7. Cheng, F. \& Chen, J. Metal-air batteries: from oxygen reduction electrochemistry to cathode catalysts. Chem. Soc. Rev. 41, 2172 (2012).

8. Muñoz-Márquez, M. Á. et al. Na-ion batteries for large scale applications: a review on anode materials and solid electrolyte interphase formation. Adv. Energy Mater. 7, 1700463 (2017)

9. Deng, J., Luo, W.-B., Chou, S.-L., Liu, H.-K. \& Dou, S.-X. Sodium-ion batteries: from academic research to practical commercialization. Adv. Energy Mater. 8, 1701428 (2018).

10. Poizot, P. \& Dolhem, F. Clean energy new deal for a sustainable world: from non- $\mathrm{CO}_{2}$ generating energy sources to greener electrochemical storage devices. Energy Environ. Sci. 4, 2003 (2011).

11. Nishide, H. et al. Organic radical battery: nitroxide polymers as a cathodeactive material. Electrochim. Acta 50, 827-831 (2004)

12. Nishide, H. \& Oyaizu, K. Materials science: toward flexible batteries. Science 319, 737-738 (2008).

13. Nishide, H., Koshika, K. \& Oyaizu, K. Environmentally benign batteries based on organic radical polymers. Pure Appl. Chem. 81, 1961-1970 (2009).

14. Janoschka, T., Hager, M. D. \& Schubert, U. S. Powering up the future: radical polymers for battery applications. Adv. Mater. 24, 6397-6409 (2012).

15. Friebe, C. \& Schubert, U. S. High-power-density organic radical batteries. Top. Curr. Chem. 375, 19 (2017).

16. Deunf, E. et al. Reversible anion intercalation in a layered aromatic amine: a high-voltage host structure for organic batteries. J. Mater. Chem. A 4, 6131-6139 (2016).

17. Kolek, M. et al. Ultra-high cycling stability of poly(vinylphenothiazine) as a battery cathode material resulting from $\pi-\pi$ interactions. Energy Environ. Sci. 10, 2334-2341 (2017).

18. Godet-Bar, T. et al. Electrochemical and ab initio investigations to design a new phenothiazine based organic redox polymeric material for metal-ion battery cathodes. Phys. Chem. Chem. Phys. 17, 25283-25296 (2015).

19. Takahashi, Y., Hayashi, N., Oyaizu, K., Honda, K. \& Nishide, H. Totally organic polymer-based electrochromic cell using TEMPO-substituted polynorbornene as a counter electrode-active material. Polym. J. 40, 763-767 (2008).

20. Yao, M., Sano, H., Ando, H. \& Kiyobayashi, T. Molecular ion battery: a rechargeable system without using any elemental ions as a charge carrier. Sci. Rep. 5, 10962 (2015).

21. Deunf, E., Jiménez, P., Guyomard, D., Dolhem, F. \& Poizot, P. A dual-ion battery using diamino-rubicene as anion-inserting positive electrode material. Electrochem. Commun. 72, 64-68 (2016).

22. Deuchert, K. \& Hünig, S. Multistage organic redox systems-a general structural principle. Angew. Chem. Int. Ed. Engl. 17, 875-886 (1978).

23. Poizot, P., Dolhem, F. \& Gaubicher, J. Progress in all-organic rechargeable batteries using cationic and anionic configurations: toward low-cost and greener storage solutions? Curr. Opin. Electrochem. 9, 70-80 (2018).

24. Liang, Y., Tao, Z. \& Chen, J. Organic electrode materials for rechargeable lithium batteries. Adv. Energy Mater. 2, 742-769 (2012).

25. Song, Z. \& Zhou, H. Towards sustainable and versatile energy storage devices: an overview of organic electrode materials. Energy Environ. Sci. 6, 2280 (2013).

26. Häupler, B., Wild, A. \& Schubert, U. S. Carbonyls: powerful organic materials for secondary batteries. Adv. Energy Mater. 5, 1402034 (2015).

27. Schon, T. B., McAllister, B. T., Li, P.-F. \& Seferos, D. S. The rise of organic electrode materials for energy storage. Chem. Soc. Rev. 45, 6345-6404 (2016).

28. Zhao, Q. et al. Rechargeable lithium batteries with electrodes of small organic carbonyl salts and advanced electrolytes. Ind. Eng. Chem. Res. 55, 5795-5804 (2016).
29. Oltean, V.-A., Renault, S., Valvo, M. \& Brandell, D. Sustainable materials for sustainable energy storage: organic Na electrodes. Materials 9, 142 (2016).

30. Zhao, Q. et al. Oxocarbon salts for fast rechargeable batteries. Angew. Chem. Int. Ed. 55, 12528-12532 (2016).

31. Jian, Z., Liang, Y., Rodríguez-Pérez, I. A., Yao, Y. \& Ji, X. Poly(anthraquinonyl sulfide) cathode for potassium-ion batteries. Electrochem. Commun. 71, 5-8 (2016).

32. Bitenc, J. et al. Anthraquinone-based polymer as cathode in rechargeable magnesium batteries. ChemSusChem 8, 4128-4132 (2015).

33. Vizintin, A. et al. Probing electrochemical reactions in organic cathode materials via in operando infrared spectroscopy. Nat. Commun. 9, 661 (2018).

34. Fan, X. et al. A universal organic cathode for ultrafast lithium and multivalent metal batteries. Angew. Chem. Int. Ed. 57, 7146-7150 (2018).

35. Sano, N. et al. Polyviologen hydrogel with high-rate capability for anodes toward an aqueous electrolyte-type and organic-based rechargeable device. ACS Appl. Mater. Interfaces 5, 1355-1361 (2013).

36. Liang, Y. et al. Universal quinone electrodes for long cycle life aqueous rechargeable batteries. Nat. Mater. 16, 841-848 (2017).

37. Perticarari, S. et al. Dual anion-cation reversible insertion in a bipyridiniumdiamide triad as the negative electrode for aqueous batteries. Adv. Energy Mater. 8, 1701988 (2018).

38. Huskinson, B. et al. A metal-free organic-inorganic aqueous flow battery. Nature 505, 195-198 (2014).

39. Beh, E. S. et al. A neutral $\mathrm{pH}$ aqueous organic-organometallic redox flow battery with extremely high capacity retention. ACS Energy Lett. 2, 639-644 (2017).

40. Orita, A., Verde, M. G., Sakai, M. \& Meng, Y. S. A biomimetic redox flow battery based on flavin mononucleotide. Nat. Commun. 7, 13230 (2016).

41. DeBruler, C. et al. Designer two-electron storage viologen anolyte materials for neutral aqueous organic redox flow batteries. Chem. 3, 961-978 (2017).

42. Winsberg, J., Hagemann, T., Janoschka, T., Hager, M. D. \& Schubert, U. S. Redox-flow batteries: from metals to organic redox-active materials. Angew. Chem. Int. Ed. 56, 686-711 (2017).

43. Zhao, Q., Zhu, Z. \& Chen, J. Molecular engineering with organic carbonyl electrode materials for advanced stationary and redox flow rechargeable batteries. Adv. Mater. 29, 1607007 (2017).

44. Chen, $\mathrm{H}$. et al. From biomass to a renewable $\mathrm{Li}_{x} \mathrm{C}_{6} \mathrm{O}_{6}$ organic electrode for sustainable Li-Ion batteries. ChemSusChem 1, 348-355 (2008).

45. Chen, H. et al. Lithium salt of tetrahydroxybenzoquinone: toward the development of a sustainable Li-ion battery. J. Am. Chem. Soc. 131, 8984-8988 (2009).

46. Armand, M. et al. Conjugated dicarboxylate anodes for Li-ion batteries. Nat. Mater. 8, 120-125 (2009)

47. Renault, $\mathrm{S}$. et al. A green Li-organic battery working as a fuel cell in case of emergency. Energy Environ. Sci. 6, 2124 (2013).

48. Wang, $\mathrm{S}$. et al. Organic $\mathrm{Li}_{4} \mathrm{C}_{8} \mathrm{H}_{2} \mathrm{O}_{6}$ nanosheets for lithium-ion batteries. Nano Lett. 13, 4404-4409 (2013).

49. Zhao, Q., Wang, J., Chen, C., Ma, T. \& Chen, J. Nanostructured organic electrode materials grown on graphene with covalent-bond interaction for high-rate and ultra-long-life lithium-ion batteries. Nano Res. 10, 4245-4255 (2017).

50. Peover, M. E. 879. A polarographic investigation into the redox behaviour of quinones: the roles of electron affinity and solvent. J. Chem. Soc. 0, 4540-4549 (1962).

51. Gottis, S., Barrès, A.-L., Dolhem, F. \& Poizot, P. Voltage gain in lithiated enolate-based organic cathode materials by isomeric effect. ACS Appl. Mater. Interfaces 6, 10870-10876 (2014).

52. Tomerini, D., Gatti, C. \& Frayret, C. Playing with isomerism and N substitution in pentalenedione derivatives for organic electrode batteries: how high are the stakes? Phys. Chem. Chem. Phys. 18, 2442-2448 (2016).

53. Lewandowski, W., Kalinowska, M. \& Lewandowska, H. The influence of metals on the electronic system of biologically important ligands. Spectroscopic study of benzoates, salicylates, nicotinates and isoorotates. Rev. J. Inorg. Biochem. 99, 1407-1423 (2005).

54. Renault, S., Brandell, D. \& Edström, K. Environmentally-friendly lithium recycling from a spent organic Li-ion battery. ChemSusChem 7, 2859-2867 (2014).

55. Ogihara, N. et al. Organic dicarboxylate negative electrode materials with remarkably small strain for high-voltage bipolar batteries. Angew. Chem. 126, 11651-11656 (2014).

56. Fédèle, L. et al. 2D-Layered lithium carboxylate based on biphenyl core as negative electrode for organic lithium-ion batteries. Chem. Mater. 29, 546-554 (2017).

57. Shimizu, A. et al. Introduction of two lithiooxycarbonyl groups enhances cyclability of lithium batteries with organic cathode materials. J. Power Sources 260, 211-217 (2014). 
58. Dietzel, P. D. C., Blom, R. \& Fjellvåg, H. Base-induced formation of two magnesium metal-organic framework compounds with a bifunctional tetratopic ligand. Eur. J. Inorg. Chem. 2008, 3624-3632 (2008).

59. Assi, H. et al. Investigating the case of titanium(IV) carboxyphenolate photoactive coordination polymers. Inorg. Chem. 55, 7192-7199 (2016)

60. Henkelis, S. E., McCormick, L. J., Cordes, D. B., Slawin, A. M. Z. \& Morris, R. E. Synthesis and crystallographic characterisation of $\mathrm{Mg}\left(\mathrm{H}_{2} \mathrm{dhtp}\right)\left(\mathrm{H}_{2} \mathrm{O}\right)_{5} \cdot \mathrm{H}_{2} \mathrm{O}$. Inorg. Chem. Commun. 65, 21-23 (2016).

61. Hay, M. B. \& Myneni, S. C. B. Structural environments of carboxyl groups in natural organic molecules from terrestrial systems. Part 1: Infrared spectroscopy. Geochim. Cosmochim. Acta 71, 3518-3532 (2007).

62. Cuisinier, M. et al. Quantitative MAS NMR characterization of the $\mathrm{LiMn}_{1 /}$ ${ }_{2} \mathrm{Ni}_{1 / 2} \mathrm{O}_{2}$ electrode/electrolyte interphase. Solid. State Nucl. Magn. Reson. 42, 51-61 (2012).

63. Morcrette, M. et al. In situ X-ray diffraction techniques as a powerful tool to study battery electrode materials. Electrochim. Acta 47, 3137-3149 (2002).

64. Zhao, L. et al. Disodium terephthalate $\left(\mathrm{Na}_{2} \mathrm{C}_{8} \mathrm{H}_{4} \mathrm{O}_{4}\right)$ as high performance anode material for low-cost room-temperature sodium-ion battery. $A d v$. Energy Mater. 2, 962-965 (2012).

65. Deng, Q. et al. Organic potassium terephthalate $\left(\mathrm{K}_{2} \mathrm{C}_{8} \mathrm{H}_{4} \mathrm{O}_{4}\right)$ with stable lattice structure exhibits excellent cyclic and rate capability in Li-ion batteries. Electrochim. Acta 222, 1086-1093 (2016).

66. Wang, L., Mou, C., Wu, B., Xue, J. \& Li, J. Alkaline earth metal terephthalates $\mathrm{MC}_{8} \mathrm{H}_{4} \mathrm{O}_{4}(\mathrm{M}=\mathrm{Ca}, \mathrm{Sr}, \mathrm{Ba})$ as anodes for lithium-ion batteries. Electrochim. Acta 196, 118-124 (2016).

67. Hernández-Burgos, K., Rodríguez-Calero, G. G., Zhou, W., Burkhardt, S. E. \& Abruña, H. D. Increasing the gravimetric energy density of organic based secondary battery cathodes using small radius cations $\left(\mathrm{Li}^{+}\right.$and $\left.\mathrm{Mg}^{2+}\right)$. J. Am. Chem. Soc. 135, 14532-14535 (2013).

68. Manthiram, A. \& Goodenough, J. B. Lithium insertion into $\mathrm{Fe}_{2}\left(\mathrm{MO}_{4}\right)_{3}$ frameworks: comparison of $\mathrm{M}=\mathrm{W}$ with $\mathrm{M}=\mathrm{Mo}$. J. Solid State Chem. 71, 349-360 (1987).

69. Manthiram, A. \& Goodenough, J. B. Lithium insertion into $\mathrm{Fe}_{2}\left(\mathrm{SO}_{4}\right)_{3}$ frameworks. J. Power Sources 26, 403-408 (1989).

70. Masquelier, C. \& Croguennec, L. Polyanionic (phosphates, silicates, sulfates) frameworks as electrode materials for rechargeable $\mathrm{Li}$ (or Na) batteries. Chem. Rev. 113, 6552-6591 (2013).

\section{Acknowledgements}

This work was funded by MNERT. The authors wish to extend a special thanks to T.

Devic, E. Deunf, J. Gaubicher and S. Perticarari (IMN) for our very fruitful discussions, as well as V. Cadiou, E. Quarez, S. Grolleau (IMN) and D. Loquet (CEISAM, Nantes, FR) for complementary experiments.

\section{Author contributions}

P.P. and N.D conceived and designed this work. A.J. performed the experiment under the guidance of P.P. and N.D. as well as under F.D. for the organic synthesis part and related characterizations. A.-C.G. carried out the TEM experiments. All co-authors analyzed the results. P.P., N.D., A.-C.G. and A.J. wrote the paper and commented on the results with the assistance of D.G. and F.D. All authors have given approval to the final version of the manuscript.

\section{Additional information}

Supplementary Information accompanies this paper at https://doi.org/10.1038/s41467 018-06708-x.

Competing interests: The authors declare no competing interests.

Reprints and permission information is available online at http://npg.nature.com/ reprintsandpermissions/

Publisher's note: Springer Nature remains neutral with regard to jurisdictional claims in published maps and institutional affiliations.

(c) (i) Open Access This article is licensed under a Creative Commons Attribution 4.0 International License, which permits use, sharing, adaptation, distribution and reproduction in any medium or format, as long as you give appropriate credit to the original author(s) and the source, provide a link to the Creative Commons license, and indicate if changes were made. The images or other third party material in this article are included in the article's Creative Commons license, unless indicated otherwise in a credit line to the material. If material is not included in the article's Creative Commons license and your intended use is not permitted by statutory regulation or exceeds the permitted use, you will need to obtain permission directly from the copyright holder. To view a copy of this license, visit http://creativecommons.org/ licenses/by/4.0/.

(C) The Author(s) 2018 